The final, definitive version of this paper has been published in Adoption \& Fostering, Vol 41 /Issue 2, 2017 by SAGE Publications Ltd, All rights reserved. (C) Jean-François Mignot

\title{
Full adoption in England and Wales and France: a comparative history of law and practice (1926-2015)
}

\section{Jean-François Mignot}

Centre National de la Recherche Scientifique (CNRS), France

\begin{abstract}
Why do the British adopt far fewer children from abroad but more domestic children than the French? To examine this question, this article compares the history of adoption law and practice in France and England and Wales. Although these countries have had similar adoption laws since the 1920s, there have long been many more adoptions in England and Wales. This is partly due to the greater numbers of abused and neglected children being put forward for adoption in the UK. In addition, memories of the forced migration of children, coupled with heated debate over transracial adoption in the 1980s, cast doubt on the idea that intercountry adoption might benefit children. Consequently, local authorities give higher priority to the placement of children born in the UK with its system of open adoption. In contrast, French prospective adopters face a dearth of domestic children available for adoption and so turn their attentions overseas.
\end{abstract}

\section{Keywords}

Abused and neglected children, best interests of the child, comparative family law, adoptions, open adoption, France, England and Wales, international comparisons,

Corresponding author:

Jean-François Mignot, Centre National de la Recherche Scientifique (CNRS), 3 rue MichelAnge, 75794 Paris, France.

Email: jeffmignot@yahoo.fr 


\section{Introduction}

France and the UK have populations of roughly the same size and their demographic characteristics are generally similar. However, while France since the 1970s has been among the countries that adopt the most children from abroad, the UK engages in even fewer intercountry adoptions than much smaller nations like the Netherlands, Sweden and Norway (Selman, 2012). At the same time, the UK undertakes far more domestic adoptions than France. Are these differences due to some distinction between French and British adoption law or are there other factors? In an attempt to answer this question, I present a comparative history of adoption law and practice in France and the UK. My analysis combines law, demography and sociology within a historical perspective. To my knowledge, this is the first article to compare the history of adoption in these two countries, although there have been comparative studies of adoption in France and another English-speaking country, namely the US, which adopts by far the largest number of children from abroad (Doumeng, 2000; Jablonka, 2005; Sagnes, 2000).

Specifically, this article compares France not with the UK as a whole but with England and Wales; these nations have different adoption laws to Scotland and Northern Ireland and also constitute the only areas for which there are long-term empirical data series. More precisely, adoptions in England and Wales are compared only with those in France that are described as 'full' (plénière). This stems from a legal instrument recognised almost everywhere (United Nations, 2009) that replaces the original tie between the adopted child and his or her biological parents. Full adoption creates a new exclusive substitute tie between adoptee and adopter, meaning that the adopted person inherits surname and inheritance rights from their adoptive parent(s) alone. This is in contrast to 'simple' adoption (adoption simple), which exists in some countries with codified Roman-Dutch law (civil law), such as France, but not in common law and other jurisdictions including all the parts of the UK (Lavallée, 2008). Simple adoption creates a parental tie between the often adult adoptee and the adopter in addition to the one they already have with their birth parents. Since England and Wales do not recognise simple adoption and this instrument usually has a quite different purpose (inheritance rather than education; see Verdier, 1988), this article only compares full adoptions in the two countries. Nor does it address in detail adoption by same-sex couples; this has only recently been made legal and comparable data are not available. 


\section{Broadly similar histories of adoption law}

How long has adoption been recognised by French and British law? Who may adopt, who may be adopted and what are the procedures and legal consequences? These are the questions that arise from a comparative history of adoption law in France (Gutton, 1993; Halifax, 2007; Neirinck, 2000) and England and Wales (Center for Adoption Policy, 2014; Flauss-Diem, 1985; Keating, 2008).

Up to the First World War

Full adoption was only introduced into French and British law after the First World War. Although childless couples had taken in orphaned or abandoned children before then, these were informal arrangements: no legal process entitled a married couple, let alone a single person, to establish an exclusive substitute tie with a non-related minor. None of the famous orphans and foundlings in 19th-century novels (e.g. Fanny Price in Jane Austen's Mansfield Park (1814); Charlotte Brontë's Jane Eyre (1847); Charles Dickens's Oliver Twist (1839) and David Copperfield (1850); Cosette in Victor Hugo's Les Misérables (1862), Rémi in Hector Malot's Sans Famille (1878) and the Vallin boy in Guy de Maupassant's Aux Champs (1882)) were actually adopted. Since there was no legal adoption instrument, a child's foster parents always ran the risk that his or her biological parents would ask to take them back. In France, the 1804 Civil Code had introduced adoption into law, but until 19 June 1923 the only legal adoption was the simple version between adults, mostly for inheritance purposes. Nor did common law in England and Wales recognise full adoption. Until the Adoption of Children Act 1926, adoption was contrary to common law's inalienability of parental rights and duties and rules for succession. Even the various child protection measures that France and Britain enacted from the late 19th century onwards did not include adoption of any sort (Daguerre, 1999).

One reason that full adoption was only introduced at a late stage was the distrust towards adopting an abandoned child who most likely had been born 'illegitimate'. Who would want a child 'born in sin' and likely to 'pass on the stigma'? Who would want their family to be tainted with the shame of a child born out of wedlock? Given these attitudes, it took the huge increase in war orphans, most of whom had married birth parents, following the death of 1,400,000 Frenchmen and 800,000 Britons in the First World War (Rohrbasser, 2014), for lawmakers in both countries to institutionalise adoption. 
Other western countries had preceded them. The US was the first to introduce full adoption into its law with an Act to Provide for the Adoption of Children in Massachusetts in 1851 and successive acts in other states until the 1870s. Similar laws were then enacted in New Zealand (1881), Western Australia (1896) and British Columbia in Canada (1920). The first countries to passed modern adoption laws were all English-speaking followers of common law.

From the 1920 s to the 1960 s

Full adoption was introduced into England and Wales by the Adoption of Children Act 1926 (followed by Northern Ireland in 1929 and Scotland in 1930). After the First World War, private charities began to arrange the placement of children with stable, respectable foster families (Keating, 2001; 2008; Rossini, 2014). From the early 1920s these voluntary agencies, among them the National Child Adoption Association (NCAA), the National Adoption Society (NAS) and the National Council for the Unmarried Mother and her Child (NCUMC), campaigned for a law to give legal status to child adoption. Their aim was that the law should enable adoption 'in the best interests of the child' (intérêt supérieur de l'enfant), and that the charities acting as intermediaries should comply with common rules that, among other things, would make it harder for unscrupulous 'baby farmers', who would take in children and sell them for adoption to anyone willing to pay.

The 1926 Act contained a number of important provisions. First, only in exceptional circumstances could a child be relinquished for adoption without the consent of their birth parents. Second, adult individuals as well as married couples could adopt without any further conditions. Third, adoption replaced the former parental tie between the adoptee and their biological family with a new tie with their adoptive family. However, until the Adoption of Children Act 1949, the adopted person could not inherit on the same terms as a 'legitimate' child.

Whereas formal adoption in England and Wales remained a largely private matter arranged by volunteers in charities until the Second World War - quite unlike the interventionism of the French state (Daguerre, 1999; Laroque and Dally, 1956) - after the war it increasingly became supervised by local authorities employing professionalised social workers in public adoption agencies. The Adoption of Children (Regulation) Act 1939, not effectively enforced until after the war, and the Adoption of Children Act 1949 brought independent, non-agency 
adoption workers under local authorities. Apart from this change, the legal adoption system in England and Wales remained more or less the same until the Adoption Act 1976.

In France, full adoption was introduced by the decree law of 29 July 1939, also known as the Family Code. After the First World War and the law of 29 June 1923, children could also be adopted, but it remained simple adoption. The 1939 Family Code contained a number of important provisions. First, a child was only available for adoption if they were orphaned or abandoned and under the age of five. Second, couples only could adopt if they had been married for more than 10 years, if one of them was aged over 40 and if they had no children of their own. Third, adoption (called 'adoptive legitimisation' or légitimation adoptive until 1966) replaced the former parental tie between the adopted person and his or her biological family with a new one, and the adoptee inherited the surname and estate of the adopter as if he or she was their child by birth. Rather as in England and Wales, the legal status of adoption was not greatly modified until the law of 11 July 1966.

\section{Since the 1960s}

Both in England and Wales and France, the 1960s and 1970s saw the liberalisation of contraception and abortion and the fading of the stigma attached to so-called illegitimate children and their mothers (witness the introduction of benefits for single-parent families). These trends reduced suspicion against adoption and increased the demand for it, but they also diminished the numbers of unwanted conceptions and births and the shame of being an 'unmarried mother'; this in turn reduced the number of children, especially newborns, given up for adoption. As a result, French and British lawmakers, increasingly wishing to protect and promote only the best interests of the child, amended some of the provisions of full adoption without affecting the general arrangements.

In France, adoption was reformed by the law of 11 July 1966, which laid down the conditions for full adoption, clarifying how a child's abandonment and consequent adoptability was to be established. Up until 1976, adopters were required to have no children of their own, so that adoption would not affect their rights, but this changed with the law of 22 December 1976 whereby parents are allowed to adopt. In terms of procedure, since the laws of 6 June 1984 and 25 July 1985, adopters have had to have official approval, in order to ensure that they have the material, psychological and parenting capacities required to promote the welfare and best interests of the child. 
In England and Wales, adoption was reformed by the Adoption Act 1976. Like the French law, it laid down the conditions for full adoption: for a child to be given up for adoption, either both parents or the child's guardian had to consent to the placement (more than six weeks after the birth) or a court must have decided in the child's interest that no parent was known or able to give consent, or that the parents had neglected or seriously abused the child. The Act also laid down that a prospective adopter had to apply to an adoption agency, unless they were related to the future adoptee. The importance of private adoption agencies in the system waned after the 1970s and by the 1990s they were only handling one-third of adoption cases (Baque, 2000).

English law, strengthened by the Children Act 1989, also stipulates that courts may decide on adoption in the sole best interests of the child, having regard to 'the ascertainable wishes and feelings of the child concerned (considered in the light of his age and understanding)' (section 1(a)) . The Adoption Act 1999 altered some provisions relating to intercountry adoption to enable the UK to ratify the Hague Convention on Protection of Children and Co-operation in Respect of Intercountry Adoption. The Adoption and Children Acts 2002 (O'Donovan, 2003) and 2014 (replacing that of 1976) are the most recent acts modernising English law on domestic and intercountry adoption with the aim of increasing the rate of adoption of children in the care of social services. In order to adopt a child, a person must be over 21 , acting alone or as a couple, married or unmarried and of persons of different or the same sex provided the partners are committed to a long-term relationship.

The current state of 'full' adoption law

French and English law on full adoption is thus fairly similar. The main aim is the same: to promote the best interests of the adopted child. Attitudes have shifted in the same way in both countries: lawmakers see adoption as being intended no longer to satisfy the adopter's interests (in bringing up a child), let alone those of the adoptee's biological parents (in not having to bring up a child), but rather the interests of the adoptee (in having loving parents). The reason why public authorities nowadays seek to increase the rate and accelerate the process of adoption of domestic children is because it is considered to be in the children's best interests. In both countries, this aim is hampered by the numbers of children who are 'hard to place' or have 'special needs', such as older children, those with siblings, disabled or traumatised children 
Table 1. Full adoption law in England and Wales and France in 2015. ${ }^{\text {ii }}$

\begin{tabular}{|c|c|c|c|}
\hline & & England and Wales & France \\
\hline \multirow{4}{*}{ 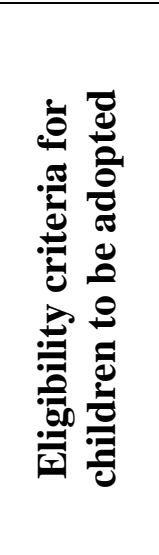 } & $\begin{array}{l}\text { Age and marital } \\
\text { status }\end{array}$ & Aged under 18 and unmarried & $\begin{array}{l}\text { Aged under } 15 \text {, at least } 15 \text { years } \\
\text { younger than the adopter }\end{array}$ \\
\hline & $\begin{array}{c}\text { Loss of parental } \\
\text { tie }\end{array}$ & $\begin{array}{c}\text { Declared available for } \\
\text { adoption by court order or } \\
\text { adoption agreed by parents }\end{array}$ & $\begin{array}{l}\text { Declared available for adoption } \\
\text { (pupille de l'État) by court order } \\
\text { or adoption agreed by parents }\end{array}$ \\
\hline & Consent & & $\begin{array}{c}\text { Consent required if adoptee is } \\
\text { aged over } 13\end{array}$ \\
\hline & $\begin{array}{l}\text { Period of } \\
\text { placement in } \\
\text { future family }\end{array}$ & At least 10 weeks & At least six months \\
\hline \multirow{2}{*}{ 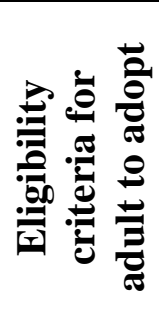 } & $\begin{array}{l}\text { Age and marital } \\
\text { status }\end{array}$ & $\begin{array}{c}\text { Aged at least } 21 \text {, or couple } \\
\text { (married or unmarried) both } \\
\text { over } 21\end{array}$ & $\begin{array}{l}\text { Aged at least } 28 \text {, or couple either } \\
\text { married for more than two years } \\
\text { or both over } 28\end{array}$ \\
\hline & Official approval & $\begin{array}{l}\text { Required, granted by adoption } \\
\text { agency }\end{array}$ & $\begin{array}{c}\text { Required, granted for five years } \\
\text { by local foster care (Aide Sociale } \\
\text { à l'Enfance) service }\end{array}$ \\
\hline \multirow{2}{*}{ 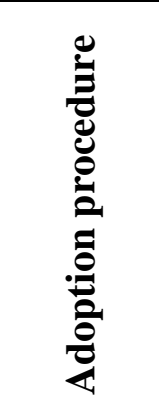 } & Administrative & $\begin{array}{l}\text { Adoption agency, which may } \\
\text { be public or an approved } \\
\text { private charity caring for } \\
\text { children available for } \\
\text { adoption, matches child and } \\
\text { adopter }\end{array}$ & $\begin{array}{c}\text { The Aide Sociale à l'Enfance, } \\
\text { which cares for children available } \\
\text { for adoption, matches child and } \\
\text { adopter }\end{array}$ \\
\hline & Judicial & $\begin{array}{l}\text { Adoption order granted by } \\
\text { family court }\end{array}$ & $\begin{array}{l}\text { Adoption order granted by } \\
\text { regional court (grande instance) }\end{array}$ \\
\hline \multirow{2}{*}{ 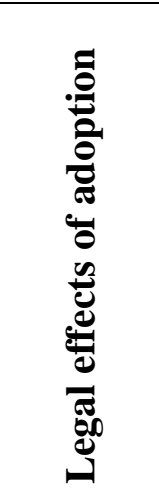 } & $\begin{array}{l}\text { Parental } \\
\text { responsibility }\end{array}$ & $\begin{array}{l}\text { Adopter and adoptee have the } \\
\text { same parental tie as any parent } \\
\text { and legitimate child. Adoption } \\
\text { is irrevocable. }\end{array}$ & $\begin{array}{l}\text { Adopter and adoptee have the } \\
\text { same parental tie as any parent } \\
\text { and legitimate child. Adoption is } \\
\text { irrevocable. }\end{array}$ \\
\hline & $\begin{array}{c}\text { Welfare } \\
\text { entitlements }\end{array}$ & $\begin{array}{l}\text { Employed adopters receive } \\
\text { adoption leave and may } \\
\text { receive adoption allowances } \\
\text { for an adopted child with } \\
\text { special needs. }\end{array}$ & $\begin{array}{l}\text { Adopters receive an adoption } \\
\text { payment or early childhood } \\
\text { benefit, and, if employees, } \\
\text { adoption leave of identical } \\
\text { duration to postnatal maternity or } \\
\text { paternity leave. }\end{array}$ \\
\hline
\end{tabular}


The provisions of adoption law are also very similar in France and England and Wales (see Table 1). Note that both countries have ratified the Hague Convention - France in 1998 and the UK in 2003 (HCCH, 2016) - and amended their laws on intercountry and domestic adoption accordingly. Seen from the point of view of English law, however, some of the French provisions are hard to comprehend. For instance, France prohibits adoption by cohabiting couples (of the opposite sex), yet allows adoption by a single person, and makes fertility treatment available to cohabiting couples of the opposite sex who have been living together for at least two years (Murat, 2008).

The major distinction between French and English law in relation to full adoption has to do with the opportunity that adopted people have to research their backgrounds, i.e. to gain nonidentifying information (parents' health, reasons and circumstances of abandonment) and even identifying information (identity of mother, father, other older and younger relatives). Adoptees are entitled to do so in England and Wales but not in France. There are two main reasons for this.

First, since the creation of the civil registry system (état civil) in 1792, French law has allowed a mother to withhold from having her name recorded on the birth certificate of her biological child, whereas under English law she is obliged to do so. Consequently, adopted children abandoned at birth find it easier to trace their families in England and Wales.

Second, although in both countries adoption gives rise to a new birth certificate, French law does not permit adoptees to consult their original birth certificates, whereas since the Adoption Act 1976, English law has allowed them to do so when they come of age. Prior to this they were unable to research their background for fear that the birth mother might interfere in the life of the adoptive family and that the child might discover their so-called 'illegitimacy', which would harm their interests. The original birth certificate, which may be obtained from the Adopted Children Register of the General Register Office, contains the date and place of birth of the adoptee, their surname at birth, mother's name, father's name if given, and the name of the person who registered the birth. Since the Children Act 1989, if both sides agree, adoptees over 18 and their biological parents may exchange information, identifying or otherwise, via an Adoption Contact Register and other intermediary agencies. In addition, since the Adoption and Children Act 2002, adoptees tracing their biological parents can consult not only their original birth certificate but also the identifying information held by adoption agencies. 
In France, it has only been since the law of 22 January 2002 that adoptees of age and their biological parents may mutually agree to exchange information via a mediating body, the Conseil National pour l'Accès aux Origines Personnelles (CNAOP). But those born anonymously (sous $X$ ) are still not entitled to know their origins; if their biological mother refuses to reveal certain information, particularly her identity, she cannot be obliged to do so. This situation is seen by many observers in the English-speaking world as an infringement of the 1989 UN Convention on the Rights of the Child, which provides that '[ $t$ ]he child shall be registered immediately after birth and shall have the right from birth to a name, the right to acquire a nationality and, as far as possible, the right to know and be cared for by his or her parents' (Article 7).

\section{Adoption figures compared}

How has adoption developed in the years since both French and English law have recognised full adoption? This section compares the number of adoptions in both countries but first a note on statistical sources.

England and Wales and France are among the few countries that have relatively long-term data series on adoption. In both nations a central administration keeps a count of adoptions and records selected characteristics of the adoptees and/or adopters. The great value of these data is that, since researchers generally do not have access to adoption files, this information is the only empirical evidence that can be used to monitor adoption in the long term. Note, however, that there is no source of information about the changing characteristics of the women or couples who have given their children up for adoption. As in most countries, this is the least understood aspect of the history of adoption, in England and Wales and France.

For France, the main source of information is a Ministry of Justice yearbook that records adoption court orders since 1952 (Ministère de la Justice, 1952-1980). The data from 1939 to 1951 are not available. Since the yearbook has provided no information on adoption since the early 1980s, it is complemented by two individual surveys carried out by the Ministry of Justice with respect to 1992 (Belmokhtar, 1996) and 2007 (Belmokhtar, 2009).

The main British source is Adoptions in England and Wales (ONS, 2014), published annually by the Office for National Statistics (ONS), recording adoption orders made since 1927. However, these adoption register data only include domestic adoptions (family and non- 
family) and not international adoptions by residents of England and Wales. Nevertheless, as we shall see, this makes no difference to the orders of magnitude and trends observed.

Since comparable data have been available, more children have always been adopted in England and Wales than the total of full adoptions in France (Graph 1). From the early 1950s to the late 1970s, the gap was quite considerable: year after year from twice to fifteen times as many children were adopted in England and Wales as in France. Since the 1980s, and especially the 2000s, the gap has shrunk dramatically. Nowadays, between 4000 and 5000 adoptions are arranged in France and in England and Wales every year.

Graph 1. Annual number of adoptees in England and Wales and France, 1927-2012.

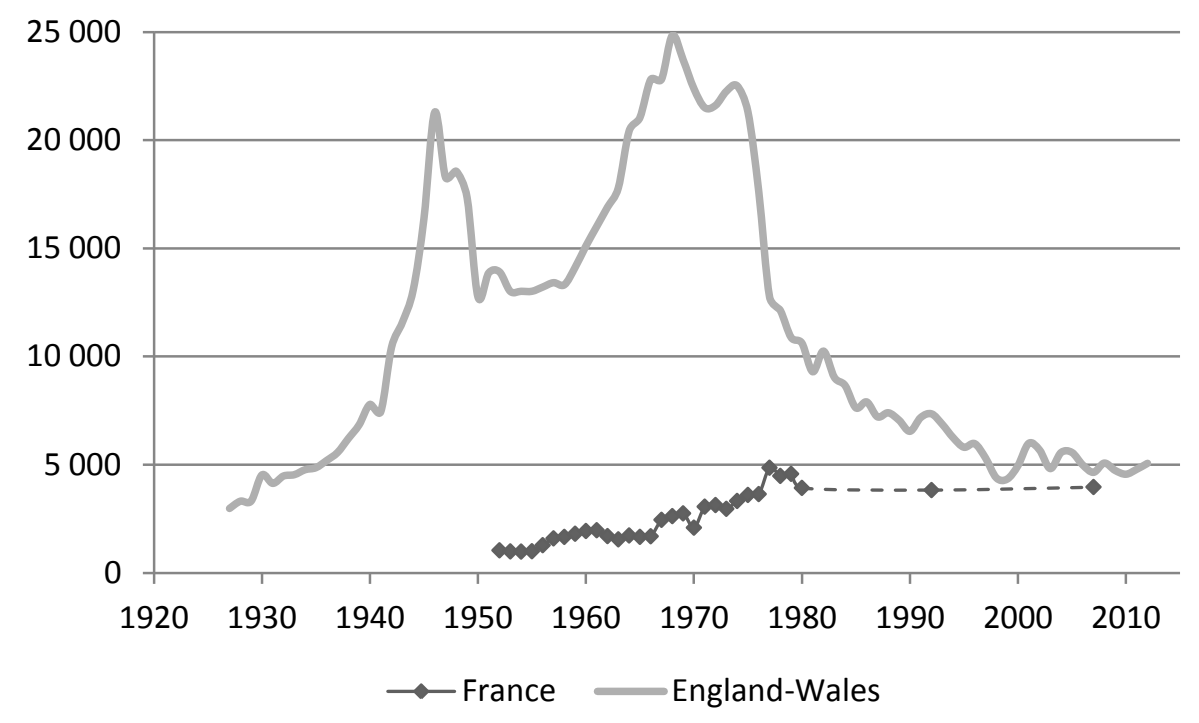

Sources: Office for National Statistics, 2014; Ministère de la Justice, 1952-1980; Belmokhtar, 1996; Belmokhtar, 2009.

The curve of annual numbers of adoptions in England and Wales is of particular interest, because it shows various phases in English demographic history since the 1930s. It rises during the first decade, peaks at a high level during the Second World War and immediately afterwards $(21,208$ adoptees in 1946), probably owing to the large numbers of war orphans and the illegitimate births that occur during most armed conflicts (plus stepchildren adopted following the post-war divorce peak). It rises again sharply in the 1960s, partly because socalled illegitimate children were more numerous and still often abandoned at birth. Then, from the late 1960s/early 1970s it plunges sharply when easier access to contraception and 
abortion and less stigma attached to illegitimacy reduced the number of newborn babies put up for adoption (Selman, 1976). Furthermore, these socio-demographic trends affecting the number of non-family adoptions were accentuated from the early 1950s by changes in the number of stepchildren adopted after their custodial parent, usually their mother, remarried (Masson, et al., 1983; Selman, 2006). In contrast, the curve of annual full adoptions in France does not clearly reflect that country's demographic history. Apart from the fact that the adoption of children by their stepfathers rarely constituted a full adoption, merely a simple one (Mignot, 2015), the vast majority of full adoptees in France since the 1980s were born abroad, so their number may be less sensitive to demographic developments in France. The historical gap between the numbers of adoptions in England and Wales and France may have various causes. This disparity certainly reflects the fact that British statistics include adoptions of related children (stepchildren, children born out of marriage, etc.) whereas French statistics do not (in France, most adoptions of related children are 'simple' adoptions). Indeed, from 1959 to 1975 there were from three to 14 times more adoptions of unrelated children in England and Wales than in France (Ministère de la Justice, 1952-1980; Selman, 2006). But this is not the whole story.

An adoption of an unrelated child can only occur after three consecutive events: a child, often out of wedlock, is born; the child is an orphan or abandoned or removed from their parents and put up for adoption; and the child is adopted (Fisher, 2003). Consequently any variations in the number of adoptions may in theory be explained by three other factors.

First, since England and Wales have usually seen fewer births to unmarried parents than France (Graph 2), the higher number of English adoptions of unrelated children cannot obviously be due to a higher number of births out of wedlock. Although it is true that such births were higher in England and Wales than France from 1962 to 1971, there were also more adoptions of unrelated children in England and Wales - both before and following this brief period. 
Graph 2. Annual births out of wedlock in France and England and Wales, 1920-2013.

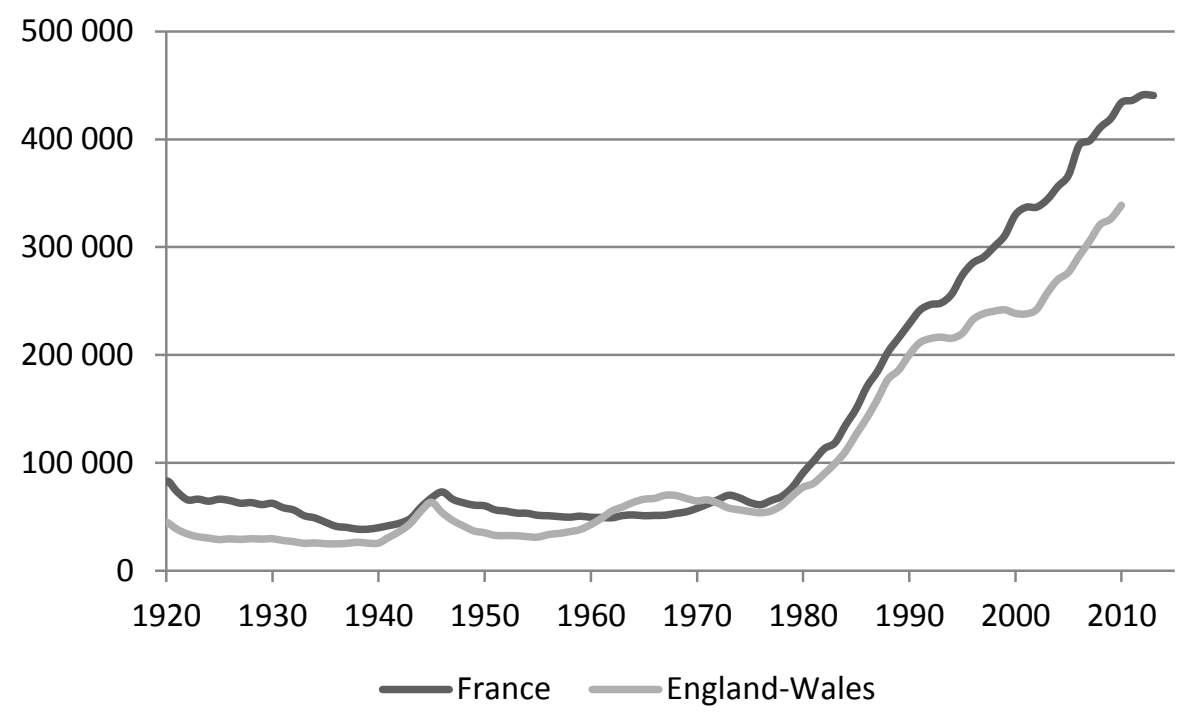

Source: Institut National d'Études Démographiques, 2016.

Second, since the rate of granting placement orders that allow a child to be adopted is, at least at present, higher in England and Wales than France (Table 2), one might in theory explain some of the gap by the higher rate of children available who are actually adopted. The adoption rate for children available for adoption in France in 2012 was 30\%, the figure in England and Wales was roughly 43\%. Despite this fact, in both France and England and Wales, domestically born healthy children available for adoption are in high demand, so the adoption rate of children available for adoption in the two countries is unlikely to have been very different in the long term. 
Table 2. Children in public care placed for adoption in France and England and Wales in 2012.

\begin{tabular}{|c|c|c|}
\hline & France & England and Wales \\
\hline $\begin{array}{c}\text { Number of children in public care placed } \\
\text { for adoption }\end{array}$ & $2328^{*}$ & $7960 * *$ \\
\hline Annual number of children adopted & $731^{*}$ & $3450 * * *$ \\
\hline
\end{tabular}

* Observatoire National de 1'Enfance en Danger, 2007-2013

** England only. Social and General Statistics, 2014

*** Department for Education, 2013

Note: The number of children in public care placed for adoption is counted on 31 December 2012 in France and 31 March 2012 in England and Wales; in each country the annual number of children adopted refers to the 365 days before that date.

The third and main reason that England and Wales have long adopted many more unrelated children than France, however, is probably that the adoption rate for domestically born children is much higher. From the 1950s onwards, as child protection increasingly became the responsibility of professional social workers, more children were removed from abusive parents and taken into care by social services (Keating, 2008). Some, albeit a minority, of these children taken into care were placed for adoption, usually without the consent, indeed against the wishes of their parents. In contrast, in France, the authorities have been reluctant to place for adoption children (even infants) removed from abusive parents.

Put another way, the child's right to permanent family care is considered as much more important in England and Wales than in France. As a result, whereas in 2012 in England only (without Wales), there were 7960 children in care and theoretically available for adoption, in France the number was only 2328 - well under a third (Table 2). According to our analyses, this is probably an important reason why the number of adoptions of unrelated children has for a long time been higher in England and Wales than in France. Whereas in England and Wales it quite often happens that children removed from their parents are put up for adoption, so more children are available for adoption and adoptions may be more frequent, in France this occurs far less. 


\section{Differing profiles of domestic adoptees}

The fact that more children removed from their parents are put up for adoption in England and Wales than in France has not only increased the number of children available for adoption (and adopted) in the former. It may also have affected the make-up of the populations of children available for adoption and adoptees, even if the data available do not always make it possible to establish comparisons of the required rigour.

Note first that in terms of the gender and age of children available for adoption and adopted, there is no major perceptible difference between France and England and Wales, and no clear development over time. These are not the characteristics that differ between adoptees in the two countries (Ministère de la Justice, 1952-1980; Belmokhtar, 1996; 2009; Office for National Statistics, 2014).

The proportion of adoptees born to unmarried parents has long seemed much higher in France than in England and Wales. From the 1950s to the 1970s, the majority of full adoptees in France were wards of the state (pupilles de l'État), i.e. children with no family, overwhelmingly born 'illegitimate' and abandoned at birth. Since the 1980s, this has applied to almost all domestic adoptees (Halifax, 2005; Halifax and Villeneuve-Gokalp, 2005). In contrast, in England and Wales, in the 1970s only some 55\% of adoptees were born out of wedlock (Selman, 1976). However, from the 1960s to 1975 close to $90 \%$ of domestic unrelated adoptees in England and Wales were born 'illegitimate' (between 1975 and 1985 this proportion decreased to 70\%) (Selman, 2006). Furthermore, since the 1970s the proportion of all adopted children who were born out of wedlock has regularly increased to $88 \%$ in 2012 (ONS, 2014). In other words, since at least the 1960s most unrelated adoptees were born outside marriage in both countries.

Whereas in France in 2012, only $8 \%$ of children in the care of the Aide Sociale à l'Enfance were put up for adoption following complete termination of parental responsibility, in England and Wales the figure is probably much higher. Unfortunately it is difficult to measure; we know only that in 2012, $62 \%$ of children in the care of social services, whether they were put up for adoption or not, had been placed there after the termination of parental responsibility following maltreatment involving serious neglect or physical, sexual or psychological violence. Whatever the case, the proportion of adoptees who have been the victims of mistreatment is probably higher in England and Wales (nearly 50\%) than in France. So we may identify two distinct profiles for domestic adoptees. In France domestic 
full adoptees were almost all abandoned at birth, while in England and Wales a large proportion were not; they were taken into care by social services without or against the consent of the parent(s).

To understand this major difference between the countries, it must first be recalled that in France, at least until the 1980s, social workers saw their child protection mission as being incompatible with reporting abusive parents to the police (Serre, 2001; 2010). Their fear was that reporting children 'in danger' would place their function of 'social control', or even as 'informers' and 'moral guardians', ahead of their mission to protect children. Although nowadays French social workers are less reluctant to report children in danger, specialist and public debates on whether the child-family tie should be maintained show that lawmakers, perhaps under the influence of family pressure groups, feel some reluctance to make mistreated children available for adoption (Vabre, 2005). This unwillingness might be due partly to their attachment to anonymous birth, which is seen not only as a woman's right but also as a way to prevent infanticide. France has thus lagged noticeably behind England and Wales in child protection (Furedi, 2002), and in noting the 'ethno-racial' identity of parents in the social treatment of abuse (Brophy, 2008). That said, the position in France is changing and there is now more questioning of 'maintaining the family tie at all costs' (Dini and Meunier, 2014).

As for the characteristics of adopters, there is little difference between the countries. In both England and Wales and France, since the 1930s, most have been infertile married couples of sufficient means. The proportion of married couples was 82\% in France in 2007 and $90 \%$ in England and Wales in 2012. Since the Children Act 1975, there have been fewer and fewer (full) adoptions of related children such as stepchildren (Masson, et al., 1983), making English and Welsh adopters more similar to their French counterparts. More recently, a few adopters have been same-sex couples. In the first quarter of 2013, this applied to $6 \%$ of adoption orders issued in England and Wales (Ministry of Justice, 2013).

\section{Numbers of international versus domestic adoptions in each country}

At present, adoption law, the annual number of adoptees and adopter profiles are relatively similar in all three countries. However, in addition to disparities in the likelihood of domestic adoptees' having been removed from their family of birth, there are major differences in adoption practice. 
England and Wales: very few children adopted from abroad

Whereas most children adopted in France in the 2000s were born overseas, the vast majority of adoptees in England and Wales were born there. Specifically, over 70\% of full adoptees in France are from abroad (Denéchère, 2011) compared to only 5\% in England and Wales. This is a major distinction. From 1993 to 2013, the mean annual number of international adoptions to France was 3200, peaking to 4136 in 2005 (Ministère des Affaires étrangères, 2016). In precisely the same period, the mean annual number of international adoptions to the UK was 240, with a maximum of only 368 in 2005 (Selman, 2006; 2015).

Among western countries it is England and Wales rather than France that seem to represent a 'special' case (Selman, 2012). So why do the British adopt relatively few children from abroad? There are a number of explanations.

First, given the history of forced emigration of orphaned or poor British children to Canada, Australia, New Zealand and South Africa from 1860 to 1960 (Melville and Bean, 1989), one may suppose that British social workers have long found it difficult to imagine that sending a child from one country to another might be in that child's best interests. This is perhaps why, until the 1990s, there were no agencies in England or Wales that helped British parents arrange international adoptions although there have been exceptions in times of international crises, such as for Basque children in the 1930s and Romanian orphans in the 1980s. As a result, some countries of origin did not deal with the UK and some adopters had to resort to US agencies. That the British history of forced emigration of children may have had longterm consequences on the number of international adoptions to England and Wales is also testified by the parliamentary discussions in the 1990s comparing British child migrants with intercountry adoptees (Select Committee on Health, 1998):

Potential future difficulties related to inter-country adoptions which may mirror some of the current concerns of former child migrants about their identity and past were brought to our attention in both New Zealand and Australia. We note from a recent Written Answer that 1,066 inter-country adoption applications have been processed in the UK since 1992. We urge extreme caution when considering these applications. Removing children from their country of birth should not be seen as an alternative to appropriate child care or occur because insufficient aid or assistance is available. 
Second, the cost of international adoption in England and Wales is likely to be much higher than domestic adoption. Social services charge a lot for international adoption procedures, bringing the total cost up to about 30,000 euros (including transport, foreign accommodation and foreign legal costs), whereas domestic adoption is virtually free. In the UK, 'only the wealthiest families can use international adoption. Unlike in France, adoption orders granted are not the same for those adopting from the UK as from abroad, and an international adoption order is extremely expensive' (Halifax, 2007: 120-121).

Furthermore, since the Adoption and Children Act 2002, if the international adoption is from a country that has not ratified the Hague Convention, the adoption order is not recognised in the UK, so the adopters have to live six months in the child's home country before securing the agreement of the British authorities and then obtain a further order in the UK. This costs time as well as money. The authorities in England and Wales most probably welcome this cost discrepancy between domestic and international adoptions, because it incentivises prospective adopters to adopt children at home, thus reducing care costs for local authorities. In other words, with a large number of looked after children available for adoption, the authorities in England and Wales are concerned about the best interests of those children (and also of their taxpayers). In contrast, in France the small number of children available for adoption reduces any interest the authorities might have in discouraging international in favour of domestic adoption.

This hesitancy about international adoptions reflects a cultural inheritance peculiar to Britain, namely the policy of shipping poor children to the colonies, a practice that continued until the 1950s, and the arguments that erupted in the 1970s about the desirability for same race foster and adoption placements. This led to the 1989 Children Act specifying that, wherever possible, children should be matched to carers for culture, religion and language and so raised some fundamental questions about the merits of adopting from overseas.

Third, it may well be that the relatively high number of domestically born children placed for adoption in England and Wales is enough to meet the demand from most prospective adopters. Why go through long and expensive international procedures when one lives in one of the few western countries where there are children born locally who are available for adoption and why adopt a child from a different ethnic group when there are native children available? In other words, it may be that in England and Wales so few children are adopted from abroad because by putting so many of their own children up for adoption, agencies can 
use domestic adoption to meet much of the demand from prospective adopters. Those prospective parents looking abroad may be those frustrate by the domestic process or seeking very young children who are becoming less available.

\section{France: few 'open' adoptions}

Whereas almost all adoption orders in France are 'closed', meaning the adopted child is not entitled to exchange information with his or her biological family, many adoption orders granted in England and Wales are for 'open adoption', where the adoptee can exchange specific information with their birth family. Among western countries, here it is France rather than England and Wales that is the 'odd one out'. Since the 1980s there have been 'open adoptions' in the US (Carp, 1998; Doumeng, 2000; Hollinger, 2000; Howell, 2009), Canada (Goubau, 2000) and Germany (Wenner, 2000). This type of adoption can take two forms that must be kept distinct, even if they are both agreed upon by the biological and adoptive parents: semi-open and full open adoption.

With semi-open adoption, the members of the adoptive family only exchange non-identifying information with the biological parents. Once the adoptee comes of age, adoption agencies or civil registry officials are allowed to consult the adoptee's original birth certificate, but may not pass on any identifying information about the birth parents. So the adoptee may be given certain facts about their biological parents or any siblings (age, medical history, physical characteristics and 'ethno-racial' identity, educational level, occupation, religion) or details of their abandonment (place of birth, reason for abandonment, etc.).

In the case of full open adoption, the members of the adoptive family exchange identifying information with the biological parents. When the adoptee comes of age, they are allowed to consult their original birth certificate and/or adoption file, and may directly contact their biological parents and siblings, so that they can write to each other or even arrange one or more meetings. The two families are thus able to identify one another in order that adopted children can learn more about their background. In England and Wales, most children adopted from care maintain contact with their birth families, not only by anonymised letters but also through meetings, which, if not frequent, may be regular (once or twice a year).

Why is there no open adoption in France? As we have seen, France adopts few children born domestically (the only ones eligible for open adoption) and most of these were deliberately abandoned by their mother or both parents at birth. Consequently, they have never had any 
ties with their biological parents. So why have open adoption in order to maintain ties that have never existed? Surely this would put off many prospective adopters and risk disrupting the adoptive placement. In contrast, in England and Wales many domestic adoptees will have been removed from their parents by a court order but the option of open adoption enables children to maintain contact, as far as this is in their interest, with birth relatives.

\section{Conclusion}

There is much to be learned from comparing full adoption in England and Wales and France. First, although adoption law in both countries has been fairly similar, England and Wales have long seen many more adoptions than France. This is partly due to the fact that in England and Wales abused domestically born children are more often placed for adoption, even against their parents' wishes. Second, since the 1970s, fewer children have been adopted from abroad in England and Wales than in France. British memory of the forced migration of children and the desirability of matching culture, language and religion whenever possible seem to cast doubt on the idea that intercountry adoption might be good for children, and the British authorities are primarily concerned with arranging the adoption of their high number of children born domestically. Third, since the 1970s too, in England and Wales many more adoptions have been 'open' than in France; again this is intended to serve the best interests of the adopted children, who may wish for information on their origins from an early age. By contrast, French couples face a dearth of domestic children available for adoption, which is why they turn their attention overseas.

This article is intended only as a contribution to the understanding of adoption in Europe, for this is a relatively undeveloped field for research. We already know some of the long-term consequences of adoption on the welfare of the adoptee, both in France (Biehal, 2012; Dumaret and Coppel-Batsch, 1998; Feast et al., 2013; Halifax, 2000; Halifax and Labasque, 2013) and the UK (Mather, 2007; Rutter et al., 2009; Triseliotis et al., 2005; Wijedasa and Selwyn, 2011). More comparative research may, however, be envisaged, because since the 1950s these two countries have adopted the same theoretical framework: insecure attachment to mother or father, lack of parental care, let alone abandonment or abuse, are considered likely to cause various emotional and cognitive disorders, such as systematic distrust of others, difficulty committing emotionally to a relationship with an adult and fear of abandonment (Savard, 2010; Schofield and Beek, 2006). Furthermore, we still know little 
about the effects of each country's adoption system on the welfare of children adopted from abroad (Greenfield, 1995).

\section{Acknowledgements}

I wish to thank Anne Daguerre, Juliette Halifax, Peter Selman, June Thoburn and the journal's referees for their advice. 


\section{References}

Baque, L. (2000) Le rôle des services et agences d'adoption en Angleterre in Fine, A. and Neirinck, C. (eds.), Parents de sang, parents adoptifs. Approches juridiques et anthropologiques de l'adoption. France, Europe, USA, Canada, Paris: LGDJ, 103-116. Belmokhtar, B.(1996) Les adoptions simples et plénières en 1992. Infostat Justice, 46:1-4. Belmokhtar, Z. (2009) L'adoption simple et plénière en 2007: des projets différents. Infostat Justice, $106: 1-6$.

Biehal, N. (2012) Outcomes of Adoption: Findings from Research in England in Quatrième Colloque suisse sur l'adoption internationale. Berne: Bundesamt fur Justiz, p42-44.

Brophy J. (2008) Child Maltreatment in Diverse Households: Challenges to Law, Theory and Practice. Journal of Law and Society, 35 (1):75-94.

Carp E. Wayne (1998) Family Matters: Secrecy and Disclosure in the History of Adoption. Cambridge: Harvard University Press,

Center for Adoption Policy, Overview of English Adoption Law 2014. Available at <http://www.adoptionpolicy.org/pdf/eu-england.pdf>.

Daguerre A. (1999) La protection de l'enfance en France et en Angleterre, 1980-198., Paris: L'Harmattan,.

Denéchère Y (2011) Des enfants venus de loin. Histoire de l'adoption internationale en France, Paris: Colin.

Department for Education (2013) Children looked after in England. Available at $<$ https://www.gov.uk/government/statistics/children-looked-after-in-england-includingadoption>.

Dini M.and Meunier M. (2014) Rapport d'information fait au nom de la commission des affaires sociales sur la protection de l'enfance, $\mathrm{n}^{\circ}$ 655. Available at <http://www.senat.fr/rap/r13-655/r13-6551.pdf>.

Doumeng V. (2000) Étude comparative de l'adoption française et de l'adoption ouverte aux États-Unis in Fine F. and Neirinck C. (eds.), Parents de sang, parents adoptifs. Approches juridiques et anthropologiques de l'adoption. France, Europe, USA, Canada, Paris: LGDJ, 147-167. 
Dumaret A-C. and Coppel-Batsch M. (1998) Effects in Adulthood of Separations and Longterm Foster Care. A French Research Study. Adoption \& Fostering, 22 (1): 31-39.

Feast F., Grant M., Rushton A.,, Simmonds J. and Sampeys C. (2013) Adoption, Adversity and Afterwards: A mid-life follow-up study of women adopted from Hong Kong. London: BAAF.

Fisher A. (2003) Still 'Not Quite As Good As Having Your Own'? Toward a Sociology of Adoption. Annual Review of Sociology, 29 (1):. 335-361.

JFlauss-Diem F. (1985) Angleterre. Revue internationale de droit comparé, 37 (3) : 539-556. Furedi F. (2002) Paranoid Parenting: Why Ignoring the Experts May Be Best for Your Child, Chicago: Chicago Review Press.

Goubau D. (2000) Open adoption' au Canada in Fine A. and Neirinck N. (eds.), Parents de sang, parents adoptifs. Approches juridiques et anthropologiques de l'adoption. France, Europe, USA, Canada, Paris: LGDJ, 63-85.

Greenfield J. (1995) Intercountry Adoption: A comparison between France and England. Adoption \& Fostering, 19 (2): 31-36.

Gutton J-P. (1993) Histoire de l'adoption en France. Paris: Publisud, Hague Conference on Private International Law, Status table, 2016. Available at < https://www.hcch.net/en/instruments/conventions/status-table/?cid=69> Halifax, J. (2000) L'insertion sociale des enfants adoptés. Résultats de l'enquête 'Adoption internationale et insertion sociale, Dossiers et recherches de l'Ined, 98 : 1-57.

Halifax J. (2005) Grandir hors de sa famille biologique. Cadre de vie des pupilles de l'État et des enfants adoptés. Recherches familiales, 2 : 47-67.

Halifax J. (2007) L'adoption plénière en France: de l'établissement d'une filiation légale à la constitution d'une filiation sociale. Demography thesis, Lille: Atelier national de reproduction des thèses.

Halifax J. and Villeneuve-Gokalp C. (2005) Adoption in France: who are the adopted children and who are the adopters? Population and societies, 417: 1-4.

Halifax J. and Labasque M-V (2013, Étude relative au devenir des enfants adoptés en France et à l'international. Rapport final, Amiens: CREAI de Picardie,. 
Hollinger J. (2000) L'adoption ouverte aux États-Unis in Fine A. and Neirinck C. (eds.), Parents de sang, parents adoptifs. Approches juridiques et anthropologiques de l'adoption. France, Europe, USA, Canada, Paris: LGDJ, 45-61.

Howell S. (2009)Adoption of the Unrelated Child: Some Challenges to the Anthropological Study of Kinship. Annual Review of Anthropology, 38: 149-166.

Institut National d'Études Démographiques (2016) Developed country database Available at <http://www.ined.fr/fr/pop_chiffres/pays_developpes/base_pays_developpes/>.

Jablonka I. (2005)L'adoption aux États-Unis et en France (XIXe-XXe siècles)", Histoire et sociétés. 15 (3) : 56-65.

Keating J. (2008) A Child for Keeps: The History of Adoption in England, 1918-1945, Basingstoke: Palgrave Macmillan.

Keating J. (2001) Struggle for Identity: Issues Underlying the Enactment of the 1926 Adoption of Children Act.University of Sussex Journal of Contemporary History, 3:. 1-9. PLaroque P. and Daly A. (1956) Les travailleurs sociaux en France et en Angleterre. Enquête sur le personnel social et médico-social familial dans les deux pays, Geneva: W.H.O.

Lavallée L. (2008) Pour une adoption sans rupture du lien de filiation d'origine dans les juridictions de civil law et de common law, Informations sociales, 146 (2) : 132-140.

Masson J. Norbury D. and Chatterton S. (1983) Mine, yours, or ours? A study of step-parent adoption, London: HMSO.

Mather M. (2007) Intercountry Adoption. Archives of Disease in Childhood, 92: 479-482.

Melville J. and Bean P. (1989) Lost Children of the Empire, London: Unwin Hyman.

Mignot J-F. (2015) Simple Adoption in France. Revival of an Old Institution (1804-2007).

Revue Française de Sociologie, 56 (3) : 525-560.

Ministère de la Justice, Compte général de l'administration de la Justice civile et commerciale et de la Justice criminelle, Paris: Ministère de la Justice, 1952-1960.

Ministère de la Justice, Compte général de l'administration de la Justice criminelle et de la Justice civile et commerciale, Paris: Ministère de la Justice, 1961-1976.

Ministère de la Justice, Annuaire statistique de la Justice, Paris: Ministère de la Justice, 1980. 
Ministère des Affaires étrangères, Statistiques de l'adoption internationale de l'Agence française de l'adoption, 2016. Available at http://www.agence-adoption.fr/le-paysage-deladoption-internationale/les-statistiques/

Ministry of Justice., Court Statistics Quarterly. January to March 2013", 2013. Available at <https://www.gov.uk/government/uploads/system/uploads/attachment_data/file/207804/court -stats-q1- 2013.pdf>.

Murat P. (2008) Les transformations de la famille. Quel impact sur les finalités de l'adoption? Informations sociales, 146 (2) : 20-33.

Neirinck N. (2000) L'évolution de l'adoption in Fine A. and Neirinck C. (eds.), Parents de sang, parents adoptifs. Approches juridiques et anthropologiques de l'adoption. France, Europe, USA, Canada, Paris: LGDJ, 343-361.

O’Donovan K. (2003) L'adoption dans le droit du Royaume-Uni., Revue internationale de droit comparé, 55 (4) : 845-860.

Observatoire National de l'Enfance en Danger La situation des pupilles de l'État au 31 décembre, 2007-2013. Available at <http://oned.gouv.fr/mots-cles/pupille-letat>.

Office for National Statistics, Adoptions in England and Wales”, 2014. Available at <http://www.ons.gov.uk/ons/rel/vsob1/adoptions-in-england-and-wales/index.html>.

Rodger J. (1996) Family Life and Social Control: A Sociological Perspective, London: Macmillan.

Rohrbasser J-M (2014), Hécatombe in id. (ed.). Bouleversements démographiques de la Grande Guerre, Paris: INED, 9-18.Rossini G. (2014) A History of Adoption in England and Wales, 1850-1961, Barnsley: Pen \& Sword,.

Rutter M., Beckett C., Castle J,. Kreppner J., Stevens S..and Sonuga-Barke E. (2009) Policy and Practice Implications from the English and Romanian Adoptees (ERA) Study: Forty Five Key Questions, London: BAAF.

Sagnes S. (2000) La revanche élective. Filiation adoptive et 'origines' en France et aux EtatsUnis in Fine A. and Neirinck C. (eds.), Parents de sang, parents adoptifs. Approches juridiques et anthropologiques de l'adoption. France, Europe, USA, Canada, Paris: LGDJ, 169-183. 
Savard S. (ed.),La théorie de l'attachement. Une approche conceptuelle au service de la protection de l'enfance, Paris: ONED.

Schofield G. and Beek M. (2006) Attachment Handbook for Foster Care and Adoption, London: British Association for Adoption and Fostering.

Schultheis S., Frauenfelder A. and Delay C.(2007) Maltraitance. Contribution à une sociologie de l'intolérable, Paris: L'Harmattan.

Select Committee on Health Third Report, 1998. Available at <http://www.publications.parliament.uk/pa/cm199798/cmselect/cmhealth/755/75502.htm> Selman P. (1976) Patterns of Adoption in England and Wales since 1959. Social Work Today, 7 (7): 194-197.

Selman P. (2006) Towards a Demography of Adoption: Making Sense of Official Statistics on Child Adoption and the Search for Origins, extract from a paper presented at the Second International Conference on Adoption Research, University of East Anglia, Norwich,.

Selman P. (2012) Global Trends in Intercountry Adoption: 2001-2010. Adoption Advocate, $44: 1-17$.

Selman P. (2015) Global Statistics for Intercountry Adoption: Receiving States and States of origin, 2003-201 Available at https://assets.hcch.net/docs/3bead31e-6234-44ae-9f4e2352b190ca21.pdf

Serre D. (2001) La 'judiciarisation' en actes. Le signalement d' 'enfant en danger. Actes de la recherche en sciences sociales, 136-137: 70-82.

Serre D. (2010) Les assistantes sociales face à leur mandat de surveillance des familles. Des professionnelles divisées. Déviance et société, 34 (2) :. 149-162.

Social and General Statistics (2014) Children in Care in England: Statistics. Available at : www.parliament.uk/briefing-papers/sn04470.pdf.

Triseliotis J, Feast J and Kyle F (2005) The Adoption Triangle Revisited: A study of adoption, search and reunion experiences. London: BAAF.

United Nations (2009) Child Adoption: Trends and policies, New York: United Nations Publications. 
Vabre F (2005) Le traitement politique de la maltraitance infantil. Recherches et prévisions 2: $5-16$.

Verdier P (1988) Limited adoption in France. Adoption \& Fostering 12(1): 41-44.

Wenner E (2000) Nouvelles formes d'adoption ouverte en Allemagne. In : Fine A and Neirinck C (eds) Parents de sang, parents adoptifs. Approches juridiques et anthropologiques de l'adoption. France, Europe, USA, Canada, Paris: LGDJ, pp. 87-101.

Wijedasa D and Selwyn J (2011) Transition to Adulthood for Adopted Young People: Secondary Analyses of Data from the Longitudinal Study of Young People in England (LSYPE), Bristol: Hadley Trust.

\footnotetext{
${ }^{i}$ This article is a revised and extended version of Mignot J-F (2016) L'adoption plénière en France et en Angleterre-Galles: une histoire comparée du droit et des pratiques (1926-2015). Droit et société, 93(2), 2016, pp. 417-435.
}

ii Table 1 only applies to non-family adoption since adoption by relatives, particularly of stepchildren, is subject to fewer conditions. 